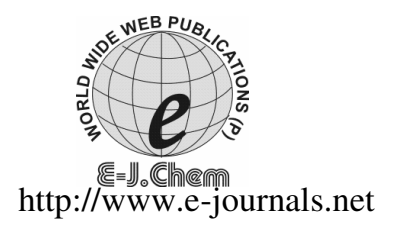

ISSN: 0973-4945; CODEN ECJHAO

E-Journal of Chemistry 2010, 7(1), 299-307

\title{
Sorption Studies of Chromium(VI) and Mercury(II) by High Temperature Activated Carbon from Syzygium Jambolanum Nut
}

\author{
S. SOPHIE BEULAH and K.MUTHUKUMARAN*
}

Department of Chemistry

Govt.College of Engineering, Tirunelveli - 627 007, Tamilnadu, India.

bamikumar@yahoo.co.in

Received 2 July 2009; Revised 2 September 2009; Accepted 12 September 2009

\begin{abstract}
High temperature activated Syzygium Jambolanum nut carbon (HSJC) has been effectively used for the removal of $\mathrm{Cr}(\mathrm{VI})$ and $\mathrm{Hg}$ (II) from aqueous solution by batch experiments. Effect of $\mathrm{pH}$, carbon dose and equilibration time were determined. Adsorption followed Freundlich and Langmuir isotherms. Kinetic studies indicated that the removal process followed reversible first order equation. Desorption of $\mathrm{Cr}(\mathrm{VI})$ was done with $1 \mathrm{M} \mathrm{NaOH}$ and $10 \% \mathrm{H}_{2} \mathrm{O}_{2}$ mixture and $\mathrm{Hg}$ (II) with $2 \% \mathrm{Na}_{2} \mathrm{~S}$ in $1 \% \mathrm{NaOH}$. The performance of HSJC was compared with a commercial activated carbon (CAC).
\end{abstract}

Keywords: Syzygium Jambolanum nut carbon, Batch experiments, Freundlich and Langmuir Isotherms, Kinetic studies, Desorption

\section{Introduction}

Pollution caused by effluents from industries is a major environmental problem faced by many countries. Wastewater discharged from industries like electroplating, textile, leather tanning, metal finishing contains $\mathrm{Cr}(\mathrm{VI})$ while the effluent from chlor-alkali plants ${ }^{1}$, painting, paper, pulp and pharmaceutical industries contains $\mathrm{Hg}$ (II). They endanger the environment, affect aquatic life and cause several health problems. $\mathrm{Cr}(\mathrm{VI})$ is carcinogenic ${ }^{2}$. $\mathrm{Hg}$ (II) damages central nervous system and brain. It also causes chest pain, renal disturbances, impairment of pulmonary function and kidney. Hence it is imperative to treat them before discharge. Methods like precipitation technique, ion exchange method, activated sludge process, electrochemical techniques are expensive. These methods lead to incomplete removal of toxic ions and cause problems in the disposal of sludge. Clean up technology in a cost effective way is the need of the hour. Adsorption by activated carbon prepared from agricultural wastes is a novel way for the removal of toxic inorganic ions from wastewater. It is a process by which the concentration of the solute is enriched at the 
surface of the adsorbent and can be desorbed by a suitable eluent. Agricultural wastes are available in plenty. Carbon prepared from agricultural wastes provides good results and involves less cost. Many agricultural wastes like coconut shell ${ }^{3}$, cotton seed ${ }^{4}$, techtona grandis bark ${ }^{5}$, pongamia leaf powder ${ }^{6}$, tamarind nut ${ }^{7}$, bamboo dust $^{8}$, palm pressed fibres ${ }^{9}$, dates nut ${ }^{10}$, turmeric wastes ${ }^{11}$ etc. have been employed to prepare the activated carbon. Syzygium Jambolanum nut which has a high medicinal value is a potential agricultural waste. The study here deals with High temperature activated Syzygium Jambolanum nut carbon (HSJC) prepared by modified dolomite process of 2050 ASTM particle size for the effective removal of $\mathrm{Cr}(\mathrm{VI})$ and $\mathrm{Hg}(\mathrm{II})$ from wastewater. The performance of the carbon was compared with a commercial activated carbon(CAC) of $M / s$ LOBA chemicals of same particle size.

\section{Experimental}

The modified dolomite process ${ }^{12}$ was used for preparation of high temperature Syzygium Jambolanum nut carbon. Fifty grams of Syzygium Jambolanum nut was placed over a bed of $\mathrm{CaCO}_{3}$ of $1 \mathrm{~cm}$ thickness. The layer on top was also covered with $\mathrm{CaCO}_{3}$ of $1 \mathrm{~cm}$ thickness and then subjected to pyrolysis at $600{ }^{\circ} \mathrm{C}$ for $1 \mathrm{~h}$. The char was then heated and maintained at $900{ }^{\circ} \mathrm{C}$ for 30 minutes for activation by $\mathrm{CO}_{2}$ liberated by the decomposition of $\mathrm{CaCO}_{3}$. The activated material was repeatedly washed with water and left soaked in $10 \% \mathrm{HCl}$ to remove the calcium oxide formed. The material was washed thoroughly with water to remove the free acid and was dried at $105 \pm 5{ }^{\circ} \mathrm{C}$. The carbon was designated as HSJC. It was ground and sieved to get 20-50 ASTM particle size.

\section{Evaluation of carbon characteristics}

The important carbon characteristics of HSJC and CAC such as bulk density, moisture content, ash, matter soluble in water, matter soluble in acid, $\mathrm{pH}$, decolourisation property, phenol number, ion exchange capacity, surface area and iron content were found out in order to determine the capacity of the carbons for the removal of contaminants by adsorption process. The results are shown in Table 1.

Table 1. Carbon characteristics.

\begin{tabular}{clcc}
\hline S.No. & \multicolumn{1}{c}{ Control tests } & HSJC & CAC \\
\hline 1. & Bulk density, g/cc & 0.60 & 0.51 \\
2. & Moisture, \% & 5.1 & 3.76 \\
3. & Ash, \% & 3.81 & 2.69 \\
4. & Matter soluble in water, \% & 1.53 & 1.09 \\
5. & Matter soluble in 0.25 M HCl, \% & 1.66 & 1.10 \\
6. & Decolourising power, mg/g & 71 & 87 \\
7. & Phenol number, mg & 25 & 22 \\
8. & Ion exchange capacity, meq./g & Nil & Nil \\
9. & Surface area, $\mathrm{m}^{2} / \mathrm{g}\left[\mathrm{N}_{2}\right.$-BET] & 646 & 629 \\
10. & pH & 6.4 & 7.1 \\
11. & Iron content, $\%$ & 0.12 & 1.1 \\
\hline
\end{tabular}

\section{Batch Studies}

Batch studies were done by using mechanical shaker. $100 \mathrm{~mL}$ of $10 \mathrm{mg} / \mathrm{L} \mathrm{Cr}(\mathrm{VI})$ solutions were taken in $300 \mathrm{~mL}$ polythene bottles for known doses of HSJC and CAC and equilibrated for $24 \mathrm{~h}$ in the $\mathrm{pH}$ range of $1-6$. Then it was filtered and analysed for $\mathrm{Cr}(\mathrm{VI})$ by using UV-Visible spectrophotometer at $540 \mathrm{~nm}$ by standard methods ${ }^{13}$. 
$100 \mathrm{~mL}$ of $10 \mathrm{mg} / \mathrm{L}$ of $\mathrm{Hg}$ (II) solutions containing $10 \mathrm{~g} / \mathrm{L}$ of $\mathrm{NaCl}$ were adjusted to different $\mathrm{pH}$ values in the range of 1-10 and known amounts of HSJC and CAC under study were added to these solutions taken in $300 \mathrm{~mL}$ polythene bottles. The solutions were equilibrated for $24 \mathrm{~h}$ in a mechanical shaker. The solutions were filtered and analysed for $\mathrm{Hg}$ (II) content using DMA ${ }^{14}$ (Direct Mercury Analyser, Milestone Inc). In DMA, the liquid sample was initially dried and then thermally decomposed in a continuous flow of oxygen. Combustion products were carried off and further decomposed in a hot catalyst bed. Mercury vapours were trapped on a gold amalgamator and subsequently desorbed for quantisation. The $\mathrm{Hg}$ content was determined using Atomic Absorption Spectrophotometry at $254 \mathrm{~nm}$. Other parameters such as effect of carbon dose at optimum $\mathrm{pH}$ and effect of equilibration time under optimum $\mathrm{pH}$ and carbon dosage were also established by the above methods for $\mathrm{Cr}(\mathrm{VI})$ and $\mathrm{Hg}(\mathrm{II})$ respectively.

\section{Adsorption isotherms}

Freundlich and Langmuir adsorption isotherm equation are the most widely used to characterise the adsorption data for adsorption in any aqueous solution. Freundlich Isotherm is represented by the equation

$$
\log \frac{x}{m}=\log +\frac{1}{n} \log C_{e}
$$

$\mathrm{k}$ and $1 / \mathrm{n}$ are the adsorption capacity and intensity of adsorption $\mathrm{x}$ is the amount of solute adsorbed, $m$ is the weight of the adsorbent and $C_{e}$ is equilibrium concentration in $\mathrm{mg} / \mathrm{L}$. Langmuir equation is given as

$$
\frac{C_{e}}{q_{e}}=\frac{1}{Q_{e} b}+\frac{C_{e}}{Q_{o}}
$$

Where, $C_{e}$ is equilibrium concentration in $\mathrm{mg} / \mathrm{L}, \mathrm{q}_{\mathrm{e}}$ is the amount adsorbed at equilibrium $(\mathrm{mg} / \mathrm{g}), \mathrm{Q}_{\mathrm{o}}$ and $\mathrm{b}$ are the Langmuir constants related to adsorption capacity and energy of adsorption.

Freundlich and Langmuir adsorption isotherm studies were carried out with different initial concentrations and fixed doses of carbon and $\mathrm{pH}$.

\section{Adsorption kinetics}

The adsorption of ions in aqueous system follows reversible first order kinetics when a single species is considered on a heterogeneous surface ${ }^{15}$. The first order rate expression ${ }^{16}$ is

where,

$$
\ln \left(1-\mathrm{U}_{\mathrm{t}}\right)=-\mathrm{kt}
$$

$$
U_{t}=\frac{C_{A(o)}-C_{A(t)}}{C_{A(o)}-C_{A(e)}}
$$

$\mathrm{C}_{\mathrm{A}(\mathrm{o})}, \mathrm{C}_{\mathrm{A}(\mathrm{t})}$ and $\mathrm{C}_{\mathrm{A}(\mathrm{e})}$ are the concentrations in $\mathrm{mg} / \mathrm{L}$ of $\mathrm{Cr}(\mathrm{VI})$ initially, at any time $\mathrm{t}$ and at equilibrium respectively. Kinetic studies were carried out at different time intervals whereas concentration, carbon doses and $\mathrm{pH}$ are fixed.

\section{Desorption}

Attempts were made to desorb the adsorbed $\mathrm{Cr}(\mathrm{VI})$ from the carbons with $1 \mathrm{M} \mathrm{NaOH}$ and $10 \% \mathrm{H}_{2} \mathrm{O}_{2}$ mixture. Desorption of $\mathrm{Hg}$ (II) was made using $2 \% \mathrm{Na}_{2} \mathrm{~S}$ in $1 \%$ $\mathrm{NaOH}^{17,18}$. 


\section{Results and Discussion}

From Figure 1, it could be seen that the optimum $\mathrm{pH}$ for $\mathrm{Cr}(\mathrm{VI})$ removal is 2 . The predominant species of $\mathrm{Cr}(\mathrm{VI})$ between 2 - 4 is $\mathrm{HCrO}_{4}^{2-}$ which is adsorbed preferentially on the adsorbents. It could be inferred from Figure 2 that for $99 \%$ removal of $\mathrm{Cr}(\mathrm{VI})$ a minimum carbon dose of $0.2 \mathrm{~g}$ of HSJC was sufficient and for CAC $0.3 \mathrm{~g}$ was needed. Figure 3 indicates that an optimum time of $5 \mathrm{~h}$ was needed for removal of $99 \%$ of $\mathrm{Cr}(\mathrm{VI})$ and $6 \mathrm{~h}$ for $\mathrm{CAC}$.

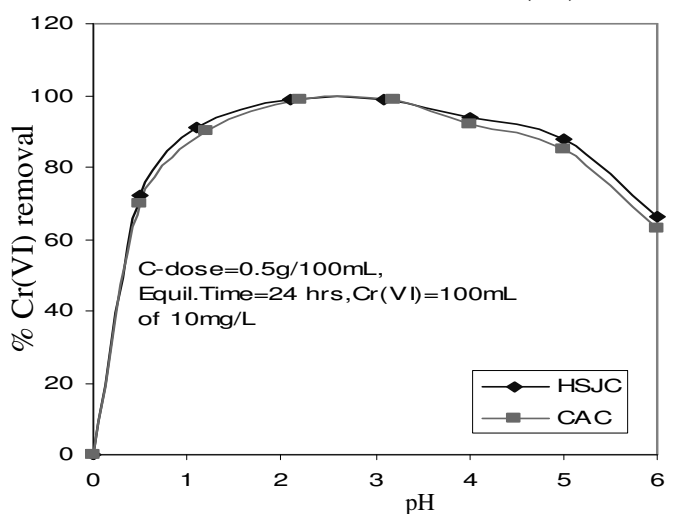

Figure 1. Effect of $\mathrm{pH}$ on removal of $\mathrm{Cr}(\mathrm{VI})$

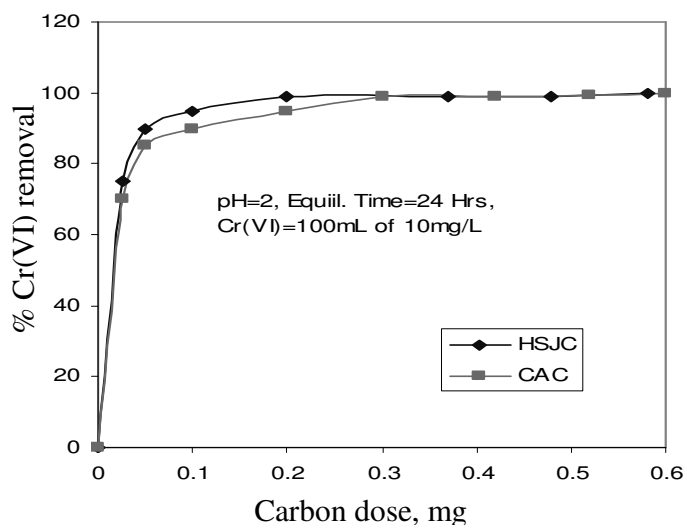

Figure 2. Effect of Carbon dose on removal of $\mathrm{Cr}(\mathrm{VI})$

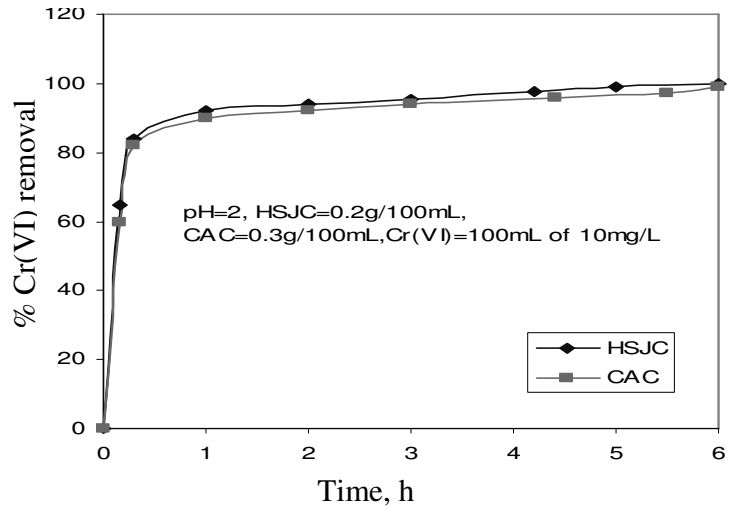

Figure 3. Effect of time on removal of $\mathrm{Cr}(\mathrm{VI})$. 
From Figure 4, it could be inferred that HSJC and CAC were effective for the quantitative removal of $\mathrm{Hg}$ (II) over the $\mathrm{pH}$ range 2 -10. So for further studies the optimum $\mathrm{pH}$ was fixed as 5 . Figure 5 shows that the optimum carbon dose required by HSJC was 0.2 $\mathrm{g}$ and for $\mathrm{CAC}$ it was $0.3 \mathrm{~g}$. Figure 6 indicates that an optimum time of $4 \mathrm{~h}$ was enough for $\mathrm{Hg}$ (II) removal and $5 \mathrm{~h}$ was required for $\mathrm{CAC}$.

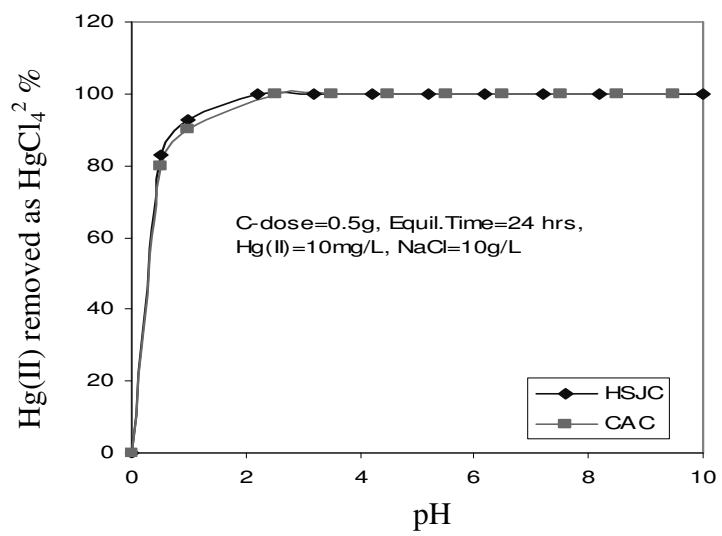

Figure 4. Effect of $\mathrm{pH}$ on removal of $\mathrm{Hg}$ (II).

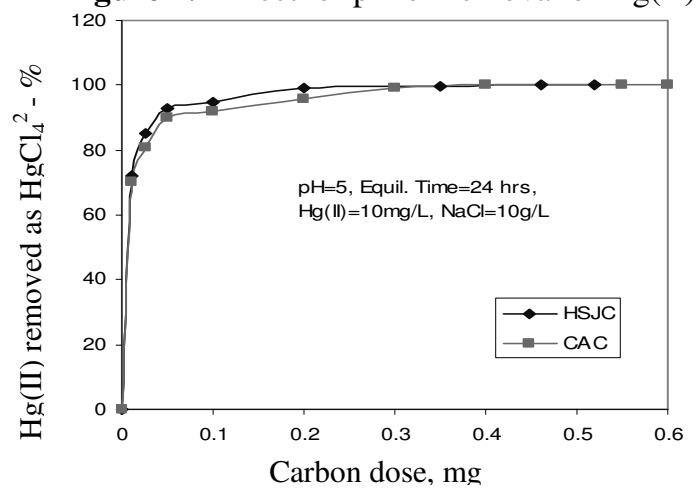

Figure 5. Effect of Carbon dose on removal of $\mathrm{Hg}(\mathrm{II})$.

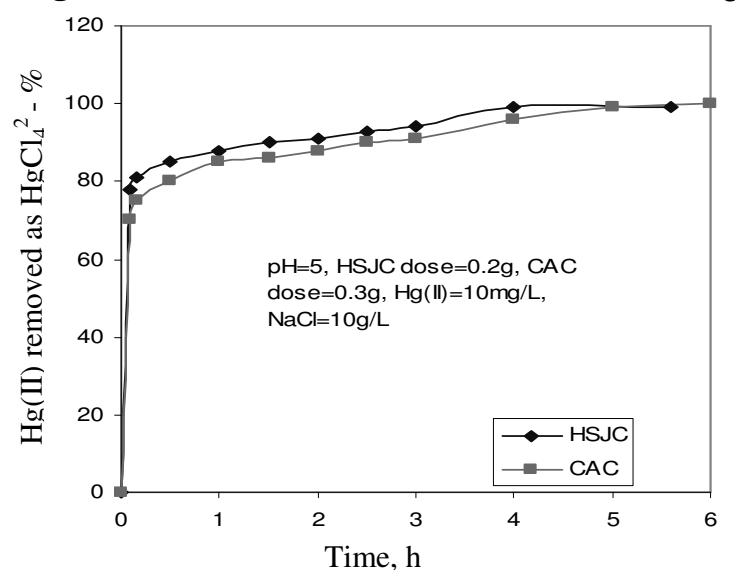

Figure 6. Effect of time on removal of $\mathrm{Hg}(\mathrm{II})$. 
Plots of $\log \mathrm{x} / \mathrm{m}$ vs. $\log \mathrm{C}_{\mathrm{e}}$ are linear for HSJC and CAC for both $\mathrm{Cr}(\mathrm{VI})$ and $\mathrm{Hg}(\mathrm{II})$ (Figure $7 \& 8$ ). The straight line nature of the plots indicates that the process followed were of Freundlich adsorption type. The $\mathrm{k}$ and $\mathrm{n}$ values for both the carbons were calculated from the intercepts and slopes respectively and are shown in Table 2 along with the regression coefficient $\left(\mathrm{R}^{2}\right)$ values. The values of $1<\mathrm{n}<10$ showed favourable adsorption of $\mathrm{Cr}(\mathrm{VI})$ and $\mathrm{Hg}(\mathrm{II})$ on both HSJC and $\mathrm{CAC}^{19}$. The regression coefficient $\left(\mathrm{R}^{2}\right)$ values were calculated and are shown in Table 2.

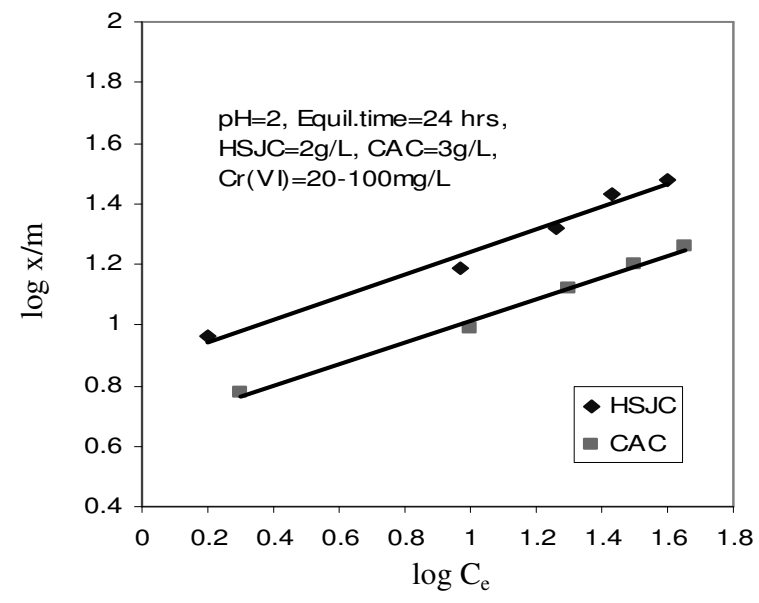

Figure 7. Freundlich adsorption isotherm for adsorption of $\mathrm{Cr}(\mathrm{VI})$.

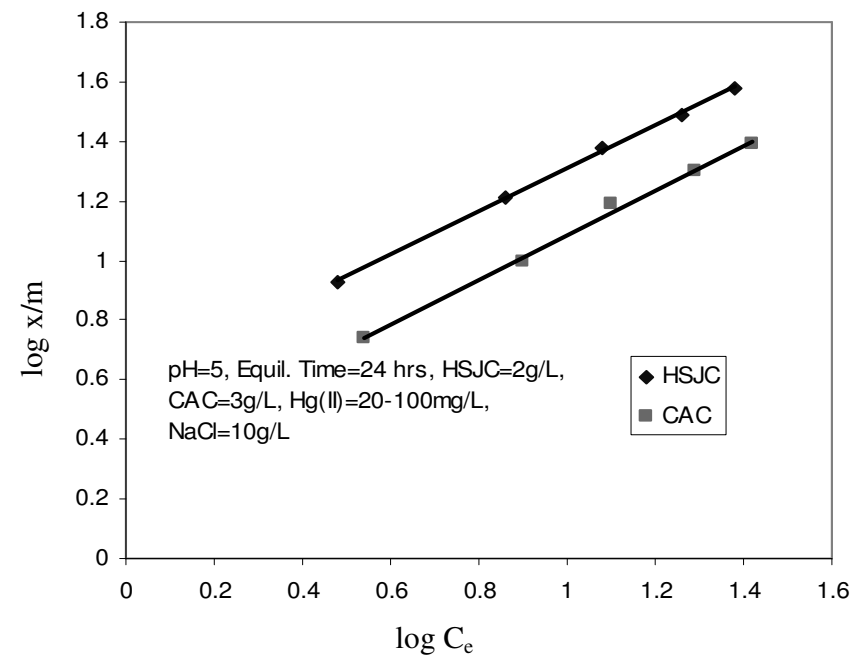

Figure 8. Freundlich adsorption isotherm for adsorption of $\mathrm{Hg}(\mathrm{II})$.

Table 2. The Freundlich adsorption isotherm values.

\begin{tabular}{ccccc}
\hline Inorganic ion & Carbon & $\mathrm{n}$ & $\mathrm{K}$ & $\mathrm{R}^{2}$ \\
\hline $\mathrm{Cr}(\mathrm{VI})$ & $\mathrm{HSJC}$ & 3 & 7.59 & 0.9814 \\
$\mathrm{Cr}(\mathrm{VI})$ & $\mathrm{CAC}$ & 2.5 & 3.8 & 0.9928 \\
$\mathrm{Hg}(\mathrm{II})$ & $\mathrm{HSJC}$ & 1.43 & 3.98 & 0.9991 \\
$\mathrm{Hg}(\mathrm{II})$ & $\mathrm{CAC}$ & 1.39 & 2.29 & 0.9959 \\
\hline
\end{tabular}


The linear plots of $\mathrm{C}_{\mathrm{e}} / \mathrm{q}_{\mathrm{e}} v s . \mathrm{C}_{\mathrm{e}}$ showed that the adsorption obeys Langmuir model for HSJC and CAC for both $\mathrm{Cr}(\mathrm{VI})$ and $\mathrm{Hg}(\mathrm{II})$ and is shown in Figure $9 \& 10 . \mathrm{Q}_{\mathrm{o}}$ and $\mathrm{b}$ were determined from Langmuir plots and are shown in Table 3 along with the regression coefficient $\left(\mathrm{R}^{2}\right)$ values. The essential characteristics of Langmuir isotherm can be expressed in terms of a dimensionless constant separation factor or equilibrium parameter $\mathrm{R}_{\mathrm{L}}$. $\mathrm{R}_{\mathrm{L}}=$ $1 / 1+\mathrm{bC}_{0}$ where $\mathrm{b}$ is Langmuir constant and $\mathrm{C}_{0}$ is the initial concentration of $\mathrm{Cr}(\mathrm{VI}) . \mathrm{R}_{\mathrm{L}}$ values between 0 and 1 indicate favourable adsorption of $\mathrm{Cr}(\mathrm{VI})$ and $\mathrm{Hg}(\mathrm{II})$ on both HSJC and CAC (Table 4). $\mathrm{R}^{2}$ value shows that Freundlich isotherm model fits well for $\mathrm{Cr}(\mathrm{VI})$ and $\mathrm{Hg}(\mathrm{II})$ adsorption for both the carbons.

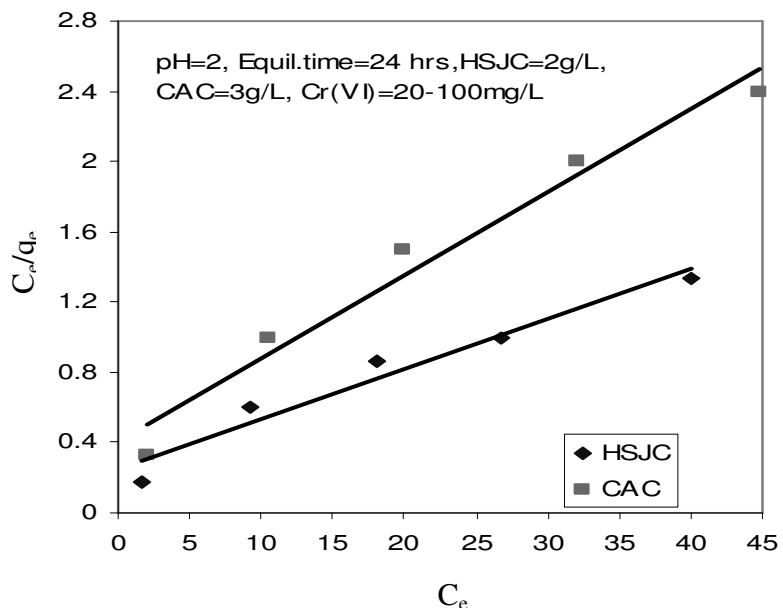

Figure 9. Langmuir adsorption isotherm for adsorption of $\mathrm{Cr}(\mathrm{VI})$.

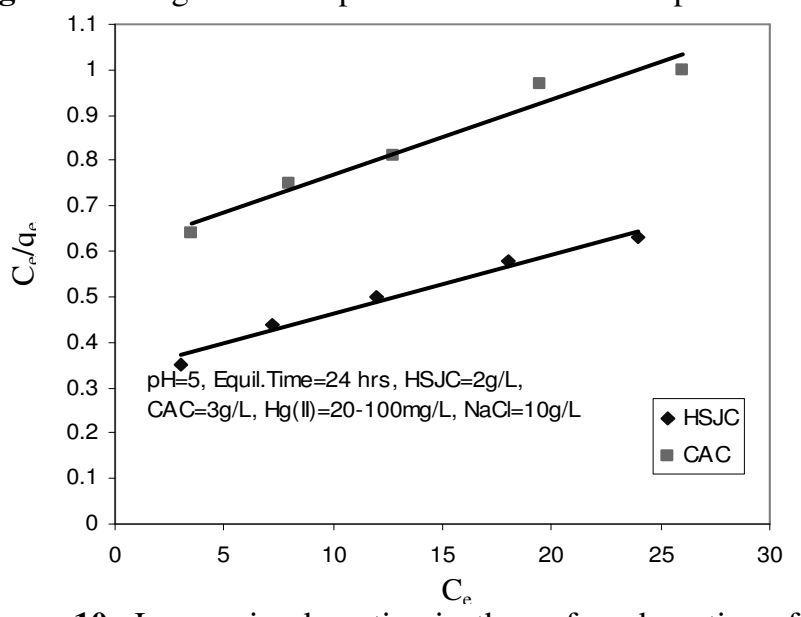

Figure 10. Langmuir adsorption isotherm for adsorption of $\mathrm{Hg}$ (II).

Table 3. The Langmuir adsorption isotherm values.

\begin{tabular}{ccccc}
\hline Inorganic ion & Carbon & $\mathrm{Q}_{0}$ & $\mathrm{~b}$ & $\mathrm{R}^{2}$ \\
\hline $\mathrm{Cr}(\mathrm{VI})$ & HSJC & 45.05 & 0.0588 & 0.9526 \\
$\mathrm{Cr}(\mathrm{VI})$ & $\mathrm{CAC}$ & 27.2 & 0.0459 & 0.9689 \\
$\mathrm{Hg}(\mathrm{II})$ & HSJC & 78.6 & 0.0364 & 0.9762 \\
$\mathrm{Hg}(\mathrm{II})$ & $\mathrm{CAC}$ & 52.9 & 0.0326 & 0.9590 \\
\hline
\end{tabular}


Table 4. Equilibrium parameter $\mathrm{R}_{\mathrm{L}}$ values for $\mathrm{HSJC}$ and CAC.

\begin{tabular}{cccc}
\hline \multicolumn{2}{c}{$\mathrm{Cr}(\mathrm{VI})$} & \multicolumn{2}{c}{$\mathrm{Hg}(\mathrm{II})$} \\
\hline HSJC & CAC & HSJC & CAC \\
\hline 0.4739 & 0.5213 & 0.5790 & 0.6053 \\
0.2309 & 0.2664 & 0.3144 & 0.3383 \\
0.1527 & 0.1789 & 0.2157 & 0.2347 \\
\hline
\end{tabular}

The straight line plot of $\ln \left(1-\mathrm{U}_{\mathrm{t}}\right)$ vs. $\mathrm{t}$ indicates that the adsorption followed reversible first order kinetics for $\mathrm{HSJC}$ and CAC for both $\mathrm{Cr}(\mathrm{VI})$ and $\mathrm{Hg}(\mathrm{II})$ (Figure 11 \& 12). The $\mathrm{k}$ adsorption values were calculated and are presented in Table 5.

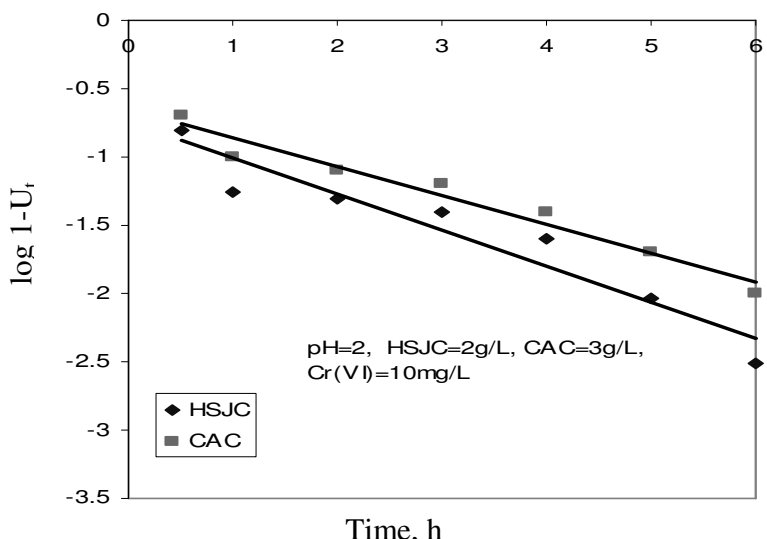

Figure 11. Kinetic fits of $\mathrm{Cr}(\mathrm{VI})$ adsorption data

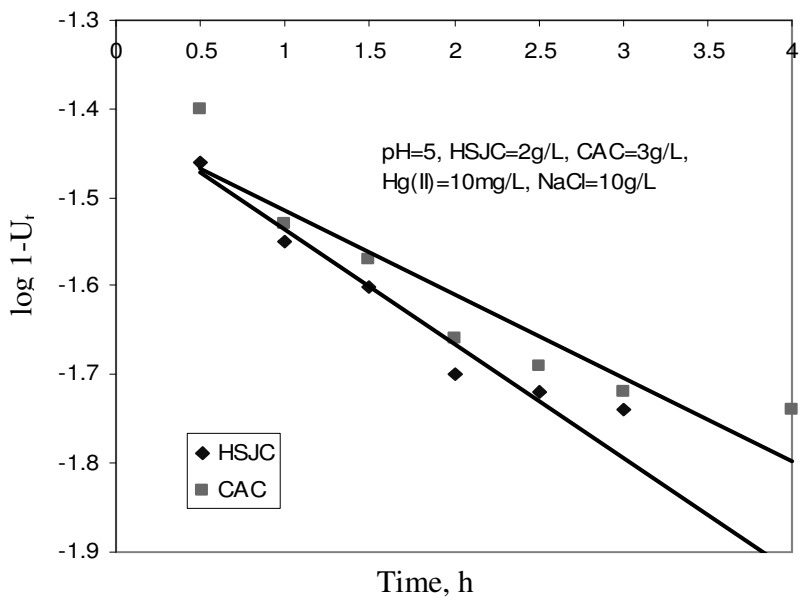

Figure 12. Kinetic fits of $\mathrm{Hg}(\mathrm{II})$ adsorption data

Table 5. Adsorption rate constants

\begin{tabular}{ccc}
\hline Inorganic ion & Carbon & $\mathrm{K}_{\text {ads }}\left(\mathrm{h}^{-1}\right)$ \\
\hline $\mathrm{Cr}(\mathrm{VI})$ & HSJC & 0.275 \\
$\mathrm{Cr}(\mathrm{VI})$ & $\mathrm{CAC}$ & 0.2222 \\
$\mathrm{Hg}(\mathrm{II})$ & $\mathrm{HSJC}$ & 0.0999 \\
$\mathrm{Hg}(\mathrm{II})$ & $\mathrm{CAC}$ & 0.095 \\
\hline
\end{tabular}


Percentage of the desorbed hexavalent chromium as chromate was found to be $81.9 \%$ for CHSJC and $80.5 \%$ for CAC. The remaining chromium which would have been reduced to $\mathrm{Cr}(\mathrm{III})$ was desorbed by adding $1 \mathrm{M} \mathrm{HCl}$. The total chromium desorbed was found to be 91.9\% for HSJC and $90.5 \%$ for CAC. $\mathrm{Hg}$ (II) forms a soluble complex $\left[\mathrm{HgS}_{2}\right]^{2-}$ with alkaline $\mathrm{Na}_{2} \mathrm{~S}$ and the desorption was found to be $98 \%$ for HSJC and $97 \%$ for CAC.

\section{Conclusion}

The study clearly shows that the High Temperature Syzygium Jambolanum Nut Carbon HSJC was superior to CAC for the removal of $\mathrm{Cr}(\mathrm{VI})$ and $\mathrm{Hg}(\mathrm{II})$ from wastewater. The adsorption conforms to Freundlich and Langmuir equation based on formation of monolayer. It followed reversible first order kinetics. Hexavalent chromium could be quantitatively desorbed by treating with a mixture of $1 \mathrm{M} \mathrm{NaOH}$ and $10 \% \mathrm{H}_{2} \mathrm{O}_{2}$. Mercury(II) could be quantitatively recovered by $2 \% \mathrm{Na}_{2} \mathrm{~S}$ in $1 \% \mathrm{NaOH}$. This environment friendly adsorbent could be used as an alternative to $\mathrm{CAC}$ for the cost effective treatment for the removal of $\mathrm{Cr}(\mathrm{VI})$ and $\mathrm{Hg}(\mathrm{II})$ from wastewater.

\section{References}

1. Selomulya C, Meeyoo V and Amal R, J Chem Technol Biotechnol., 1999, 74, 111.

2. Namasivayam C and Periyasamy K, Water Res,. 1993, 27, 1663.

3. Muthukumaran K, Balasubramanian N and Ramakrishna T V, Met Finish, 1995, 95(11), 46.

4. Lakshmi N and Srinivasan K, Oriental J Chem., 2004, 20(3), 487.

5. Deshkar A M and Dara S D, Asian Environ., 1988, 10(4), 3.

6. Sivamani S and Prince Immanuel V, J Environ Sci Eng., 2008, 50(2), 11.

7. Srinivasan K and Suganthi N, Asian J Chem., 2009, 21(6), 4515.

8. Kannan N and Veemaraj T, E Journal of Chemistry, 2009, 6(2), 247.

9. Tan W T, Ooi S T and Lee C K, Environ Technol., 1993, 14, 277.

10. Kannan N and Balamurugan J, Indian J Environ Protect., 2004, 24(5), 371.

11. Karthikeyan S, Sivakumar P and Palanisamy P N, E Journal of Chemistry, 2008, 5, 409.

12. Srinivasan K, Balasubramanian N and Ramakrishna T V, Indian J Environ Health, 1988, 30, 376.

13. Standard Methods for the Examination of Water and Wastewater; AWWA, APHA, 1973.

14. Helen M Boylan, Randy D Cain, and 'Skip' Kingston H M, J Air Waste Manage Assoc., 2003, 53, 1318.

15. Panchenkor G H and Lebeder G M, Chemical Kinetics andcatalysis; Mir Publishers, Moscow, 1976.

16. Bhattacharya K and Venkobachar C, J Environ Eng., 1984, 104, 110.

17. Vis J H, Chemical Age of India, 1980, 31(5), 481.

18. Muthukumaran K, Balasubramanian $\mathrm{N}$ and Ramakrishna T V, Indian Chem Eng., Section B, 2003, 45(2), 123.

19. Mckay G, Blair H S and Garden J, J Appl Polymer Sci., 1982, 27, 3043. 


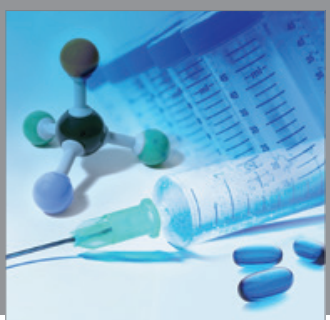

International Journal of

Medicinal Chemistry

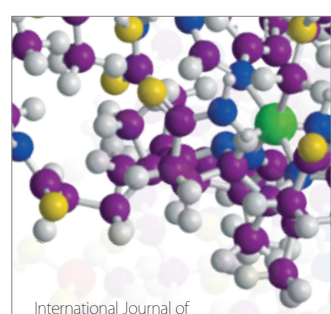

Carbohydrate Chemistry

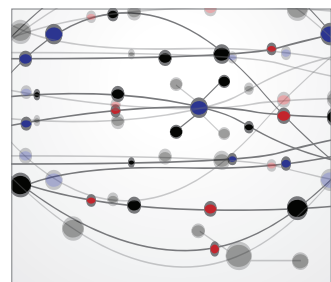

The Scientific World Journal
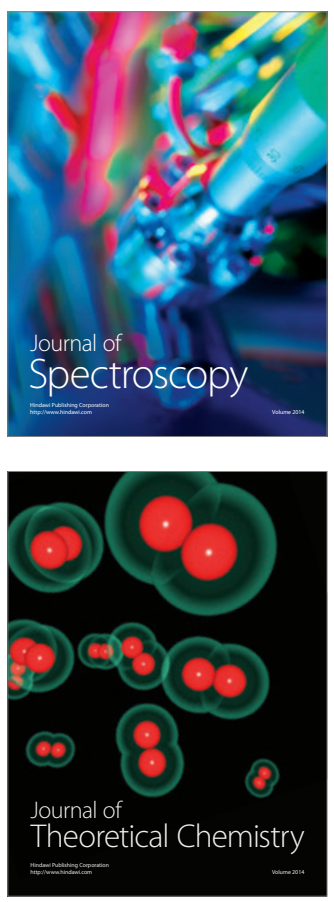
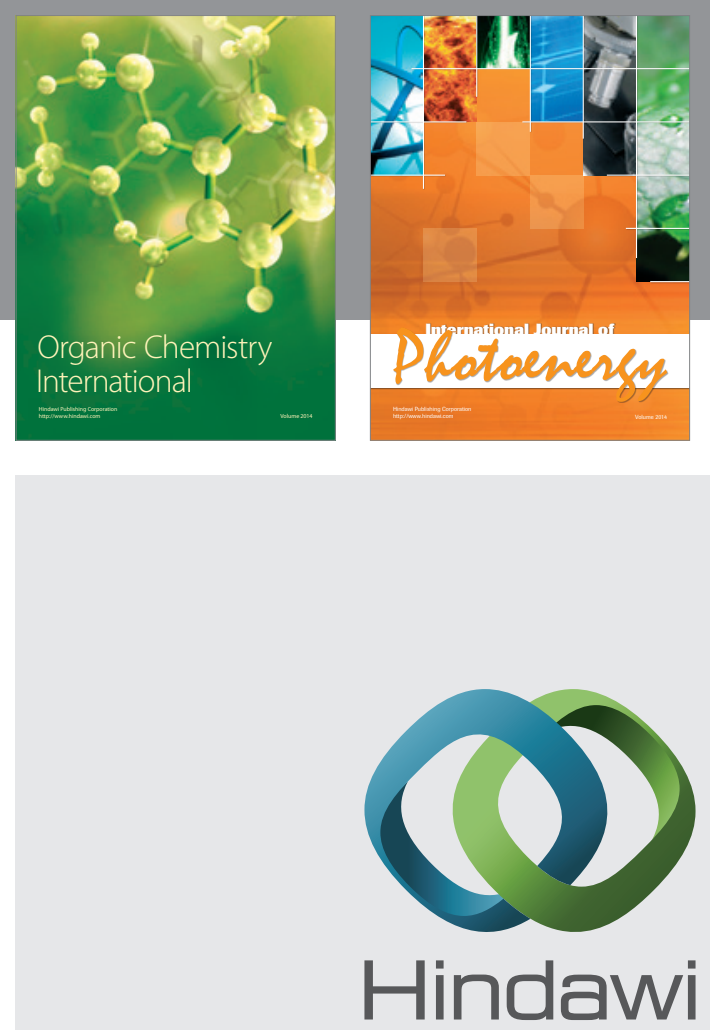

Submit your manuscripts at

http://www.hindawi.com
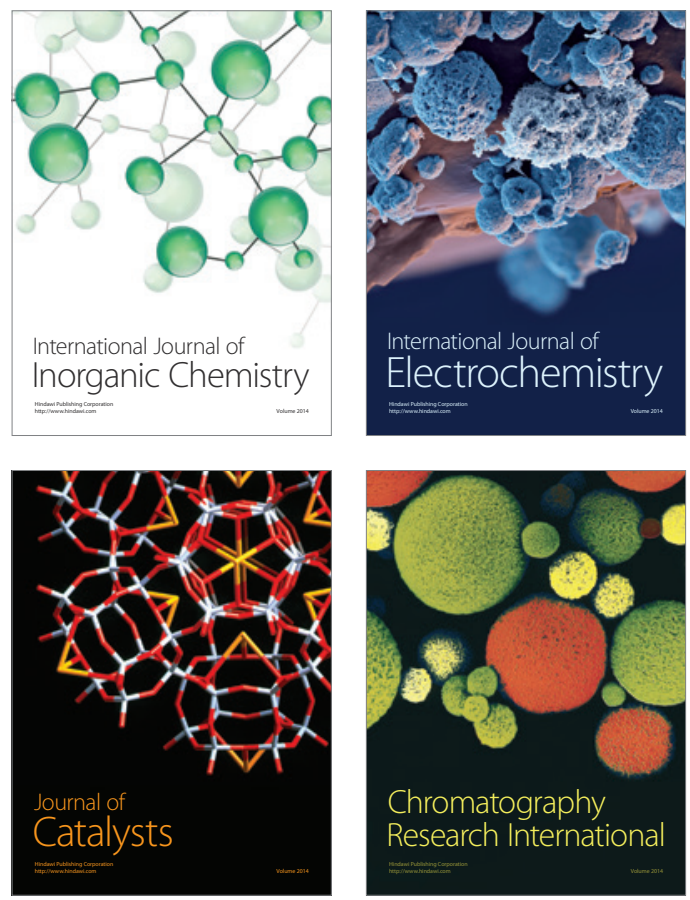
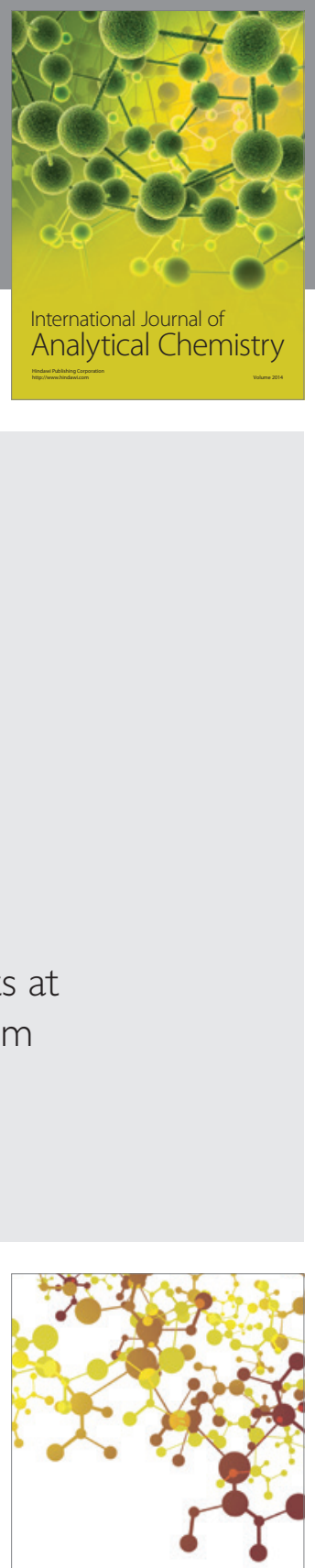

Journal of

Applied Chemistry
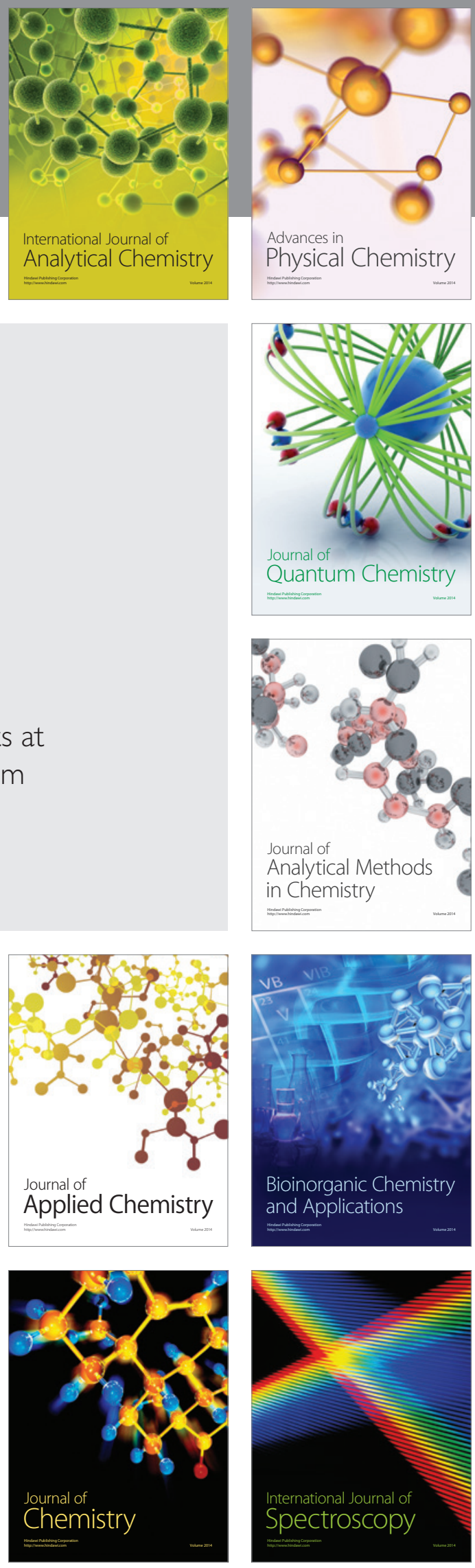